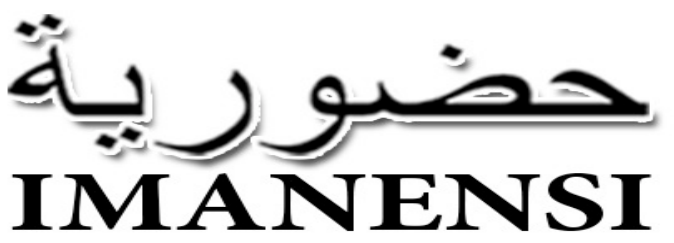

Jurnal Ekonomi, Manajemen, dan Akuntansi Islam

Vol 4, No 2, September 2019, Hlmn. 9-15

\title{
Equity-based crowdfunding sebagai alternatif penerapan akad mudharabah berbasis non bank
}

\author{
Febrina Nur Ramadhania,1,* \\ aUniversitas Brawijaya, J1. Mayjen Haryono 169 Malang, Indonesia 65145 \\ 1febrina.nr94@gmail.com* \\ * penulis koresponden
}

\begin{abstract}
Abstrak
Artikel ini bertujuan untuk mengkaji lebih jauh tentang penggunaan equity-based crowdfunding sebagai alternatif penerapan akad mudharabah yang berbasis non bank. Pada equity-based crowdfunding, penerbit adalah mudarib (wiraswasta) sementara platform crowdfunding hanya bertindak sebagai agen berdasarkan konsep wakalah. Sehingga, penerbit hanya dikenakan biaya penggunaan platform. Selanjutnya, Shahibul maal (penyedia modal) adalah investor yang telah menyumbangkan uang mereka secara online melalui platform elektronik. Tetapi harus diperhatikan di sini bahwa pada platform penjelasan tentang rasio pembagian laba dan rugi harus dicantumkan, sehingga sesuai dengan prinsip akad mudharabah.

Kata Kunci: Crowdfunding; Mudharabah; Mudarib; Bank.

Abstract

This article aims to further examine the use of equity-based crowdfunding as an alternative to the application of non-bankbased mudharabah agreements. In equity-based crowdfunding, the publisher is mudarib (entrepreneur) while the crowdfunding platform only acts as an agent based on the concept of time. Thus, publishers are only charged for using the platform. Furthermore, Shahibul maal (capital provider) is an investor who has donated their money online through an electronic platform. But it must be noted here that on the platform an explanation of the profit and loss sharing ratio must be listed, so that it is in accordance with the mudharabah contract principle.
\end{abstract}

Keywords: Crowdfunding, Mudharabah; Mudarib; Bank.

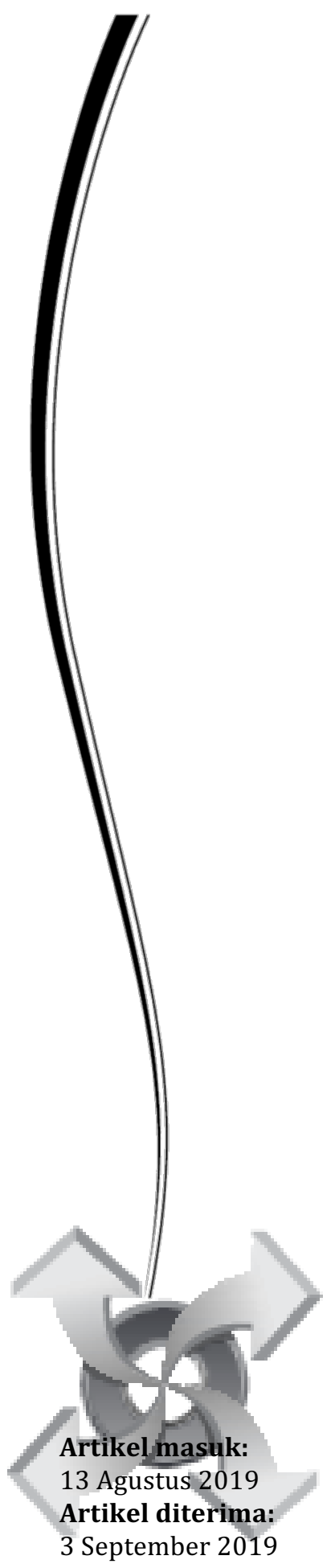




\section{PENDAHULUAN}

Mudharabah merupakan salah satu akad kerjasama dimana salah satu pihak berperan sebagai penyedia dana (shahibul maal), sedang pihak yang lain berperan sebagai pengelola dana (mudharib) (Sapuan, 2016; Shaikh, 2011). Akad ini biasa digunakan dalam Lembaga Keuangan Islam, khususnya bank. Dimana bank berperan sebagai mediator atas dana yang diinvestasikan oleh nasabah untuk disalurkan kepada pihak yang membutuhkan dana. Idealnya, pembagian hasil usaha menggunakan profit-loss sharing system (PLS). Hanya saja, tingginya resiko yang akan ditanggung oleh bank membuat sistem ini sulit diterpakan sepenuhnya oleh bank syariah (Hidayah, Lowe, \& Woods, 2018). Alternatif yang dipilih kemudian untuk mengatasi hal ini adalah dengan menggunakan profit sharing system atau net revenue sharing (Nasim \& Mediawati, 2019). Terbukti, The International Organization of Islamic Banks' menemukan, pada praktiknya hanya $20 \%$ operasional bank syariah yang menggunakan PLS (Kamla, 2009). Kondisi ini, tentu telah bergeser dari prinsip dasar bermuamalah dalam Islam.

Islam menganjurkan untuk senantiasa berbuat adil, tidak terkecuali dalam berbisnis. Dan dalam dunia bisnis dikenal istilah, "high risk, high return", prinsip inilah yang sebenarnya sejalan dengan nilai Islam. Namun, rendahnya persentase penggunaan PLS pada bank syariah, menggambarkan bahwa pada dasarnya bank belum siap menanggung segala resiko yang mungkin muncul dari kerjasama yang dijalin (Hidayah et al., 2018). Kondisi ini menyebabkan terjadinya pelimpahan resiko hanya pada salah satu pihak saja. Dalam kondisi seperti ini, sering kali mudharib menjadi pihak yang dirugikan. Atas praktik ini, bank memberi klaim bahwa hal tersebut merupakan risk control atas dana nasabah yang disalurkan. Tampak jelas kesalah pahamanan akan akad mudharabah.

Pada prinsipnya, Islam mengatur bahwa kerugian yang diperoleh dari akad mudharabah haruslah ditanggung oleh kedua belah pihak yang menjalin perikatan. Dimana, ketika kerugian terjadi, maka pemilik dana akan menanggung kerugian fiannsial, sedangkan pengelola dana akan menanggung kerugian tenaga (Chong \& Liu, 2009; Sa'diyah \& Arifin, 2013; Sapuan, 2016; Shaikh, 2011). Hanya saja, kondisi yang terjadi pada bank syariah dewasa ini justru sebaliknya. Pengelola dana menganggung kerugian atas dana yang digunakannya, sedangkan pemilik dana berhak atas dana yang diinvestasikannya. Hal inilah yang merusak akad mudharabah pada bank syariah, hingga memunculkan keraguan dikalangan masyarakat akan penerapan prinsip Islam pada operasional bank syariah.

Di Indonesia, penggunaan akad mudharabah pada bank syariah terus menurun setiap tahunnya. Berdasarkan data statistik OJK (2018), presentase pembiayaan mudharabah bank pembiayaan syairah hanya $0,5 \%$ dari keseluruhan jumlah pembiayaan yang disalurkan, dan presentase ini mengalami penurunan bila dibandingkan dengan tahun 2012 yang berjumlah 0,7\%. Padahal, Kemenperin RI (2019) melaporkan, setidaknya terdapat 59,2 juta pelaku UMKM di Indonesia. Dengan jumlah itu, tentu terdapat peluang besar dalam penerapan akad ini pada bank syariah. Karena melalui akad ini diharapkan wirausahawan Indonesia dapat mengembangkan usahanya, sehingga cita-cita besar perataan ekonomi mampu tercapai. Namun, kurang tepatnya sistem yang digunakan dalam mempraktikkan akad ini membuatnya menjadi sulit berkembang. Oleh karenanya, diperlukan alternatif lain dalam penerapan akad mudharabah. 
Seiring dengan perkembangan bisnis berbasis digital, mulai bermunculan berbagai inovasi yang bertujuan untuk memudahkan proses transaksi, salah satunya adalah crowdfunding. Crowdfunding merupakan platform yang digunakan sebagai media pengadaan dana atas suatu proyek (Abdullah \& Oseni, 2017; Schwienbacher \& Larralde, 2010). Secara garis besar, crowdfunding terbagi atas beberapa jenis, yakni donasi, reward, debtbesed, dan equity-based (Marzban, Mehmet Asutay, \& Adel Boseli, 2014). Jenis yang sering dimanfaatkan dalam dunia bisnis adalah debt-based dan equity-based. Crowdfunding perbedaan keduanya terletak pada basis pendanaan. Debt-based berbasis utang, sedangkan equity-based berbasis investasi. Oleh karenanya, praktik equity based memiliki kesamaan prinsip dengan mudharabah. Dimana, pembagian keuntungan didasarkan pada presentase yang telah disepakati pada saat menjalin perikatan, sedangkan kerugian ditanggung oleh investor. Hal lain yang menarik dari jenis crowdfunding ini adalah investor berhak memilih dimana ia akan menginvestasikan dana yang ia miliki, sehingga ia dapat memantau sejauh mana pengelolaan dana yang ia investasikan. Selain itu, berbeda dengan bank syariah yang merupakan bisnis pada sektor keuangan, bisnis yang tergabung pada crowdfunding umumnya merupakan bisnis pada sektor riil. Poin-poin tersebut tentu sejalan dengan akad mudharabah yang diatur dalam Islam. Berdasarkan latar belakang tersebut, artikel ini bertujuan untuk mengkaji lebih jauh tentang penggunaan equity based crowdfunding sebagai alternatif penerapan akad mudharabah yang berbasis non bank.

\section{HASIL DAN PEMBAHASAN}

\section{A. Akad Mudharabah Pada Bank Syariah}

Dalam operasionalnya, bank syariah berpedoman pada prinsip-prinsip mualamah dalam Islam, yakni terbebas dari unsur riba, maysir, gharar, dan bathil (Hidayah et al., 2018; Sa'diyah \& Arifin, 2013; Sapuan, 2016). Salah satu akad yang sesuai dengan prinsip muamalah Islam, adalah mudharabah. Mudharabah termasuk dalam kategori syirkah atau akad kerjasama. Merujuk pada fatwa DSN-MUI Nomor: 07/DSN MUI/IV/2000 mengenai pembiayaan mudharabah, mudharabah adalah akad kerjasama suatu usaha antara dua pihak, dimana pihak pertama sebagai shahibul maal (pemilik modal) yang menyediakan seluruh modal, sedangkan pihak kedua adalah mudharib (pengelola modal) yang bertindak sebagai penerima dan pengelola modal yang diberikan. Mengenai jangka waktu, mekanisme pengembalian modal pokok serta pembagian keuntungan ditentukan berdasarkan kesepakatan kedua pihak.

Pada bank syariah, penerapan akad mudharabah dapat dilakukan melalui dua jenis, yakni bank berperan sebagai pengelola dana (mudharib) dan bank berperan sebagai pemilik dana (shahibul maal) (Ascarya \& Yumanita, 2015). Bank berperan sebagai pengelola dana ketika bank memperoleh dana dari nasabah yang menggunakan akad mudharabah. Sedangkan, ketika bank memberikan pembiayaan kepada debitur menggunakan akad mudharabah, maka posisi bank adalah sebagai pemilik dana. Keduanya menggunakan sistem bagi hasil dalam hal pembagian keuntungan/kerugian. Untuk memperjelas dapat dilihat pada Gambar 1 mengenai proses pembiayaan mudharabah yang diterpakan pada bank syariah. 


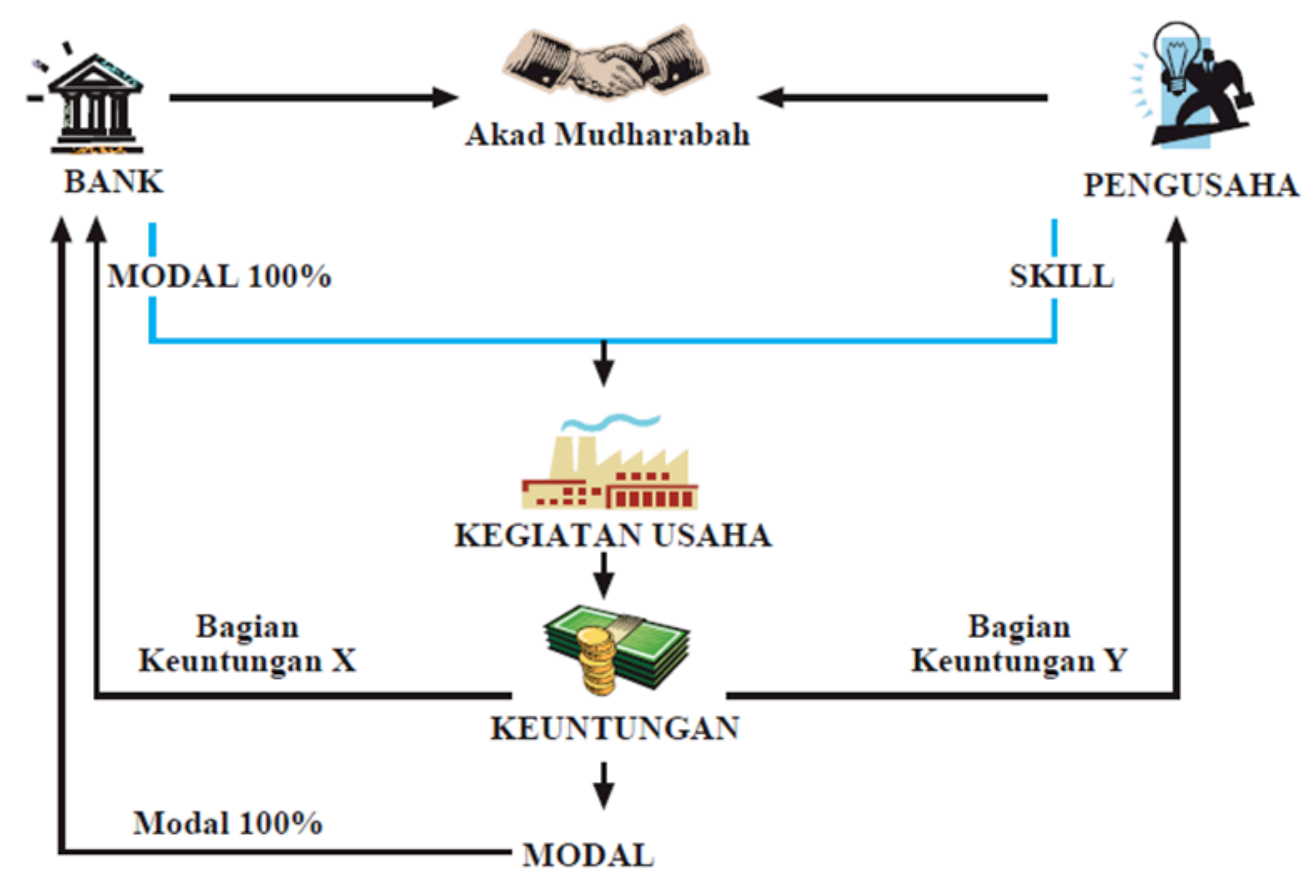

Gambar 1. Proses pembiayaan mudharabah bank syariah

Mengacu pada booklet Seri Kebanksentralan Bank Indonesia No. 14 tentang Gambaran Umum Bank Syariah, bank dapat menghimpun dana menggunakan akad mudharabah melalui dua produk, yakni tabungan dan deposito. Dalam hal ini, kerjasama menggunakan prinsip bagi hasil dan bagi kerugian. Ketika nasabah sebagai pemilik modal (shahibul maal) menyerahkan uangnya kepada bank sebagai pengusaha (mudharib) untuk dikelola, maka keuntungan yang diperoleh akan dibagi sesuai kesepakatan pada saat akad. Sedangkan ketika terjadi kerugian, maka akan ditanggung oleh nasabah selaku pemilik dana. Prinsip bagi hasil ini sering disebut dengan istilah profit-loss sharing (PLS). Sedangkan, untuk penyaluran dana, bank menggunakan akad mudharabah melalui pembiayaan, dengan prinsip bagi hasil yang sama dengan tabungan dan deposito. Hanya saja pada produk ini bank berperan sebagai shahibul maal sedangkan pengusaha berperan sebagai mudharib.

Prinsip bagi hasil tersebut, sesuai dengan ketentuan Islam atas akad mudharabah. Namun, pada praktiknya bank lebih sering menggunakan profit sharing system atau net revenue sharing (Nasim \& Mediawati, 2019). Pemilihan metode ini dikarenkan, resiko kerugian yang mungkin terjadi lebih kecil. Ketika bank menggunakan metode PLS dalam bagi hasilnya, maka pada saat terjadi kerugian, bukan hanya bank satu-satunya pihak yang akan menanggung kerugian, melainkan juga nasabah selaku pemilik dana yang dikelola oleh bank. Inilah sebabnya, penggunaan metode tersebut sering dikatakan sebagai risk control bank atas dana nasabah.

Bila dipandang dari sisi prinsip muamalah dalam Islam, maka ini tidak sesuai lagi dengan akad mudharabah yang seharusnya. Penggunaan profit sharing system atau net revenue sharing berarti pemilik modal tidak siap akan resiko kerugian yang akan dideritanya. Padahal, dalam berbisnis Islam mengharuskan untuk senantiasa berlaku adil. 


\section{B. Crowdfunding}

Secara sederhana, crowdfunding merupakan salah satu teknik pendanaan atas proyek maupun unit usaha oleh sekelompok individu yang bukan merupakan pihak professional (misalnya, bank maupun pemodal ventura) (Schwienbacher \& Larralde, 2010). Dalam sistem operasional bank, bank berperan sebagai intermedary antara pihak yang memiliki dan membutuhkan dana. Sebaliknya, operasional crowdfunding berjalan tanpa perantara. Project owner mencoba untuk memanfaatkan keramaian dengan mengumpulkan dana langsung dari individu.

Crowdfunding tampil dalam sebuah platform website yang menjadi tempat bertemunya project owner dengan publik yang memberikan dana. Nantinya, project owner akan memberikan sebuah produk atau layanannya sebagai sebagai timbal balik. Marzban et al. (2014), membagi crowdfunding menjadi empat jenis, yakni; donasi, reward, debt-besed, dan equity-based . Namun, Otoritas Jasa Keuangan (OJK) mengelompokkan crowdfunding hanya dalam tiga jenis, yakni:

1. Donation Based atau hadiah adalah penggalangan dana yang dilakukan dalam bentuk donasi. Sebagai feedback, pihak yang menyumbang akan memperoleh hadiah tertentu, tergantung pada tingkat sumbangannya. Jenis inilah yang umumnya banyak beroperasi di Indonesia.

2. Debt Based, dalam skema ini dana yang diserahkan adalah pinjaman dari masyarakat yang harus dikembalikan dengan skema tertentu.

3. Equity Based, dalam skema ini dana dari masyarakat mendapatkan imbalan berupa persentase saham dari proyek yang digelar. Terdapat tiga pihak utama yang menjadi pemegang kepentingan (stakeholders) yaitu entrepreneur, platform crowdfunding, dan investor (backers).

\section{Penerapan Akad Mudharabah Melalui Equity Based Crowdfunding}

Dalam Islam, mudharabah dipandang sebagai tonggak ekonomi yang dapat mewujudkan keadilan masyarakat melalui sistem bagi hasil. Proporsi bagi hasil didasarkan pada nisbah yang disepakati pada awal akad (Sa'diyah $\&$ Arifin, 2013). Penerapan akad ini, dapat dilakukan dengan menggunakan equity-based crowdfunding yang merupakan kerjsama berbasis modal.

Pada dasarnya, equity-based crowdfunding dapat tergolong dalam mudharabah maupun musyarakah. Hal ini diakrenakan keduanya tergolong akad syirkah. Namun, Abdullah \& Oseni, (2017), berpendapat bahwa pada praktiknya, penggunaan akad mudharabah lebih mudah daripada musyarakah. Terdapat beberapa keuntungan equity-based crowdfunding dari perspektif keuangan Islam yakni:

1. Menggunakan sistem bagi hasil sehingga resiko ditanggung bersama

2. Mengurangi kesenjangan pendanaan karena akses modal disediakan untuk berbagai pengusaha

3. Menjadi peluang investasi baru bagi investor kecil dan menengah

4. Mendorong inovasi

5. Menciptakan dan meningkatkan peluang kerja dengan pendirian perusahaan baru

Secara sederhana, equity-based crowdfunding dilakukan dengan skema di Gambar 2 (Abdullah \& Oseni, 2017): 


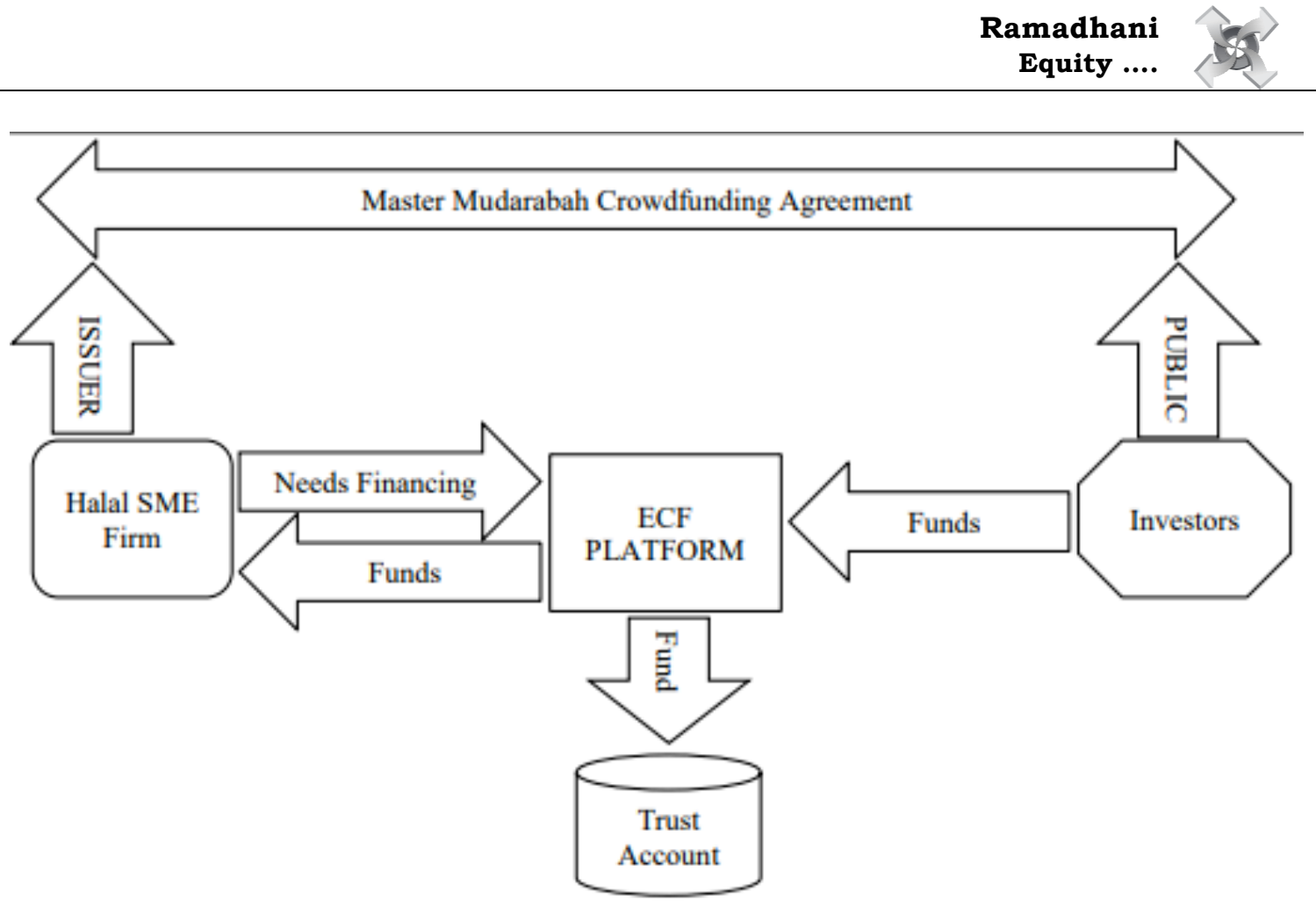

Gambar 2. Skema equity-based crowdfunding

Penerbit adalah mudarib (wiraswasta) sementara platform crowdfunding hanya bertindak sebagai agen berdasarkan konsep wakalah. Sehingga, penerbit hanya dikenakan biaya penggunaan platform. Selanjutnya, Shahibul maal (penyedia modal) adalah investor yang telah menyumbangkan uang mereka secara online melalui platform elektronik. Tetapi harus diperhatikan di sini bahwa pada platform penjelasan tentang rasio pembagian laba dan rugi harus dicantumkan, sehingga sesuai dengan prinsip akad mudharabah.

Skema ini tentu berbeda dengan skema akad mudharabah pada bank, dimana bank memiliki fungsi ganda yakni selaku shahibul maal dan mudharib. Konsep tersebut tentu memiliki resiko yang lebih besar dari pada crowdfunding yang berperan sebagai wakil. Pada operasional crowdfunding, ketika shahibul maal melakukan investasi, maka ia telah mengetahui dengan jelas bisnis apa yang ia danai. Sedangkan, ketika melakukan investasi pada bank, maka dana tersebut akan dikelola dengan diinvestasikan kembali pada bisnis yang lain. Sehingga, penggunaan crowdfunding sebagai sarana penerapan akad mudharabah akan lebih sesuai daripada penggunaan bank syariah.

Di Indonesia, praktik ini telah diterpkan pada beberapa platform seperti kerjasama.com. Kerjasama.com merupakan corwdfounding yang memasarkan bisnis pada bidang property. Harapnnya, kedepannya akan lebih banyak lagi platform sejenis yang memasarkan bisnisyang lebih beragam.

\section{SIMPULAN}

Merujuk pada fatwa DSN-MUI Nomor: 07/DSN MUI/IV/2000 mengenai pembiayaan mudharabah, mudharabah adalah akad kerjasama suatu usaha antara dua pihak, dimana pihak pertama sebagai shahibul maal (pemilik modal) yang menyediakan seluruh modal, sedangkan pihak kedua adalah mudharib (pengelola modal) yang bertindak sebagai penerima dan pengelola modal yang diberikan. Mengenai jangka waktu, mekanisme pengembalian modal pokok serta pembagian keuntungan ditentukan berdasarkan kesepakatan kedua pihak. Akad ini dapat dilaksanakan melalui equity-based 
crowdfunding. Dimana, penerbit adalah mudarib (wiraswasta) sementara platform crowdfunding hanya bertindak sebagai agen berdasarkan konsep wakalah. Sehingga, penerbit hanya dikenakan biaya penggunaan platform. Selanjutnya, Shahibul maal (penyedia modal) adalah investor yang telah menyumbangkan uang mereka secara online melalui platform elektronik. Tetapi harus diperhatikan di sini bahwa pada platform penjelasan tentang rasio pembagian laba dan rugi harus dicantumkan, sehingga sesuai dengan prinsip akad mudharabah.

\section{REFERENSI}

Abdullah, S., \& Oseni, U. A. (2017). Towards a sharī'ah compliant equitybased crowdfunding for the halal industry in Malaysia. International Journal of Business and Society.

Ascarya, \& Yumanita, D. (2015). Bank Syariah: Gamabran Umum (Seri Keban). Jakarta: Pusat Pendidikan dan Studi Kebanksentralan, Bank Indonesia.

Chong, B. S., \& Liu, M. H. (2009). Islamic banking: Interest-free or interestbased? Pacific Basin Finance Journal. https: / / doi.org/10.1016/j.pacfin.2007.12.003

Hidayah, N. N., Lowe, A., \& Woods, M. (2018). Accounting and pseudo spirituality in Islamic financial institutions. Critical Perspectives on Accounting. https://doi.org/10.1016/j.cpa.2018.09.002

Kamla, R. (2009). Critical insights into contemporary Islamic accounting. Critical Perspectives on Accounting. https://doi.org/10.1016/j.cpa.2009.01.002

Marzban, S., Mehmet Asutay, \& Adel Boseli. (2014). Shariah-compliant Crowd Funding: An Efficient Framework for Entrepreneurship Development in Islamic Countries. Harvard Islamic Finance Forum. https://doi.org/10.13140/RG.2.1.2696.1760

Nasim, A., \& Mediawati, E. (2019). Critical Study the Application of the Principle of Profit Sharing in Syirkah Mudharabah and Musyarakah in Islamic Banking. KnE Social Sciences. https: / / doi.org/10.18502/kss.v3i13.4289

OJK. (2018). Statistik Perbankan Syariah. Jakarta: Otoritas Jasa Keuangan.

Sa'diyah, M., \& Arifin, M. A. (2013). Mudharabah Dalam Fiqih Dan Perbankan Syari'Ah. Equilibrium : Jurnal Ekonomi Syariah, 1(Desember), 302-323.

Sapuan, N. M. (2016). An Evolution of Mudarabah Contract: A Viewpoint From Classical and Contemporary Islamic Scholars. Procedia Economics and Finance. https://doi.org/10.1016/S2212-5671(16)00043-5

Schwienbacher, A., \& Larralde, B. (2010). Crowdfunding of Small Entrepreneurial Ventures. In https://doi.org/10.2139/ssrn.1699183

Shaikh, S. A. (2011). A Critical Analysis of Mudarabah \& A New Approach to Equity Financing in Islamic Finance. Journal of Islamic Banking \& Finance. https://doi.org/10.1017/CBO9780511753756 